\title{
Immune exhaustion during chronic infections in cattle
}

\author{
Satoru KONNAI ${ }^{1{ }^{*}}$, Shiro MURATA ${ }^{1)}$ and Kazuhiko OHASHI ${ }^{1)}$ \\ 1)Department of Disease Control, Graduate School of Veterinary Medicine, Hokkaido University, Sapporo \\ 060-0818, Japan
}

J. Vet. Med. Sci.

79(1): 1-5, 2017

doi: 10.1292/jvms.16-0354

Received: 6 July 2016

Accepted: 27 September 2016

Published online in J-STAGE:

8 October 2016
ABSTRACT. Recently, dysfunction of antigen-specific T cells is well documented as T-cell exhaustion and has been defined by the loss of effector functions during chronic infections and cancer in human. The exhausted T cells are characterized phenotypically by the surface expression of immunoinhibitory receptors, such as programmed death 1 (PD-1), lymphocyte activation gene 3 (LAG-3), T-cell immunoglobulin and mucin domain-containing protein 3 (Tim-3) and cytotoxic T-lymphocyte antigen 4 (CTLA-4). However, there is still a fundamental lack of knowledge about the immunoinhibitory receptors in the fields of veterinary medicine. In particular, very little is known about mechanism of T cell dysfunction in chronic infection in cattle. Recent our studies have revealed that immunoinhibitory molecules including PD-1/ programmed death-ligand 1 (PDL1) play critical roles in immune exhaustion and disease progression in case of bovine leukemia virus (BLV) infection, Johne's disease and bovine anaplasmosis. This review includes some recent data from us.

KEY WORDS: bovine leukemia virus, immune checkpoint, immune exhaustion, programmed death 1, programmed death-ligand 1

In recent years, it has been suggested that various immunosuppressive factors are involved in the progression and maintenance of refractory diseases, such as chronic infections and cancer, and these have been shown to constitute a part of the mechanism allowing immune evasion by infected cells and tumor cells. In such diseases, immunosuppressive factors, such as programmed death 1 (PD-1), are expressed on effector cells at increased levels and bind to their respective ligands to induce immune exhaustion of the effector cells $[2,4,5,49]$. This results in markedly reduced cell proliferation, cytokine production and cytotoxic activity. However, as this reaction is reversible, antibody-based means to inhibit the immunosuppressive function are being studied. For example, the administration of anti-programmed death-ligand 1 (PD-L1) or anti-PD-1 antibodies capable of suppressing PD-1 signaling has been reported to enhance the proliferation and cytokine production of pathogen- or tumor-specific T cells as well as the expression of effector molecules $[2,4,5,49]$. Thus, the functional inhibition of immunosuppressive factors represents a viable means to reactivate immune cells in a state of tolerance and is anticipated to be applicable as a new therapeutic strategy for chronic infections or tumor diseases or as an approach to enhance the efficacy of vaccines. This control method is characterized by anti-pathogen and anti-tumor effects being mediated by multifunctional actions, including promotion of cell proliferation, production of various cytokines and cytotoxic function, and because of unlike administration of cytokine alone or adoptive cellular immunotherapy, it targets effector cells. For example, in a simian immunodeficiency virus (SIV) experiment conducted as a model of human immunodeficiency virus (HIV) infection, anti-PD-1 antibody treatment has been reported to have a virus-eliminating effect and marked survival benefit [52]. However, such studies have been still limited in the fields of veterinary medicine (Table 1). Recent studies in our laboratory have revealed that immunoinhibitory molecules including PD-1/PD-L1 play critical roles in immune exhaustion and disease progression in several chronic diseases of animals. Among them, we are currently conducting analyses on the tumor disease bovine leukemia virus (BLV) infection and chronic cattle infection, such as Johne's disease, which present with intractable diarrhea.

\section{TOPICS ON THERAPEUTIC AGENTS TARGETING PD-1/PD-L1}

The immunosuppressive receptor PD-1 and its ligand PD-L1 have been identified by Dr. Tasuku Honjo and his colleagues at the Kyoto University as factors that induce programmed cell death [15]. Since the mechanism mediated by PD-1 and its ligand was shown to be important for immune suppression and tolerance, it has also been reported to be involved in pathogenetic mechanisms

*Correspondence to: Konnai, S., Mailing address: Department of Disease Control, Graduate School of Veterinary Medicine, Hokkaido University, Sapporo, Hokkaido 060-0818, Japan. e-mail: konnai@vetmed.hokudai.ac.jp

(C2017 The Japanese Society of Veterinary Science

This is an open-access article distributed under the terms of the Creative Commons Attribution Non-Commercial No Derivatives (by-ncnd) License <http://creativecommons.org/licenses/by-nc-nd/4.0/>. 
Table 1. Research on immune checkpoints in veterinary medicine

\begin{tabular}{lll}
\hline \multicolumn{1}{c}{ Species } & \multicolumn{1}{c}{ Disease } & \multicolumn{1}{c}{ References } \\
\hline Cattle & Bovine leukemia virus infection & {$[$ in this review (see Table 2)] } \\
& Johne's disease & {$[19,31]$} \\
& Bovine anaplasmosis & {$[29]$} \\
& Bovine viral diarrhea virus infection & {$[35]$} \\
Pig & Porcine circovirus type 2 infection & {$[38,39,54]$} \\
& Porcine reproductive and respiratory syndrome virus infection & {$[38,39]$} \\
& Classical swine fever virus infection & {$[55]$} \\
& Swine torque teno viruses infection & {$[43]$} \\
Sheep & Respiratory syndrome virus infection & {$[44-46]$} \\
Dog & Canine cancer & {$[10,20,21,37,42,50]$} \\
& Canine leishmaniasis & {$[3,6,40]$} \\
Cat & Feline immunodeficiency virus infection & {$[1,7]$} \\
\hline
\end{tabular}

of various diseases [32]. PD-1 and PD-L1 are single-pass transmembrane molecules expressed on the cell surface, which belong to the B7 family. Their expression is induced by immune-activating stimuli and is understood as a negative feedback mechanism to suppress excessive immune reactions and let immune responses cease. When the receptor PD-1 is bound by its ligand, src homology 2-domain-containing tyrosine phosphatase 2 (SHP-2) and SHP-1 are recruited to immunoreceptor tyrosine-based inhibitory motif and immunoreceptor tyrosine-based switch motif in the intracellular region of PD-1 and suppress antigen receptor signaling mediators [33]. This process results in reduced production of cytokines, such as interferon (IFN)- $\gamma$ and interleukin (IL)-2, reduced cell proliferation and suppressed immune cell activation. In addition to the close involvement in homeostasis of the living body as summarized above, recent studies have shown that immunosuppressive factors, PD-1 and PD-L1, are also involved in immunosuppression in cases of tumors and chronic infections. While generally not highly expressed in normal tissues, PD-L1 is expressed at a high rate in tumor tissues in melanoma, lung cancer, colorectal cancer and ovarian cancer, and has been demonstrated to be involved in immune evasion by tumors [5]. In patients with renal cell cancer and gastric cancer, PD-L1 has been shown to be an important prognostic determinant; also, the disease progression is faster, and the mortality is higher in patients with tumors expressing PD-L1 than in patients without detectable PD-L1 expression [51, 53]. In addition, PD-L1 expression has also been reported for other tumors including breast cancer, pancreatic cancer and bladder cancer, and PD-1 expression in tumor-infiltrating lymphocytes has been confirmed in many types of tumors including melanoma, lung cancer and intrahepatic bile duct cancer. These findings have revealed the importance of the PD-1/PD-L1 pathway as an immunosuppression mechanism in a variety of tumors. Based on the series of studies on PD-1/PD-L1 in tumor diseases, therapeutic means targeting this pathway are being developed. Specifically, these new therapeutics are biopharmaceuticals based on anti-PD-1 antibodies, anti-PD-L1 antibodies or recombinant proteins that inhibit the PD-1/PD-L1 pathway. These biopharmaceuticals have been reported to show good anti-tumor effects regardless of the tumor type and are attracting growing attention as a new, promising class of anti-tumor therapy. Fully humanized anti-PD-1 and anti-PD-L1 antibodies have already been produced and are actively tested as therapeutic agents in clinical studies (trials), with good anti-tumor effects continuing to be reported in patients with melanoma, lung cancer, renal cell cancer and some other types of cancer. In melanoma, which has a very poor prognosis, clinical trials conducted in Japan and the United States have reported not only the suppressed growth of cancer cells, but also complete remission in some cases. On September, 2014, the anti-PD-1 antibody "opdivo" (nivolumab) was finally released by Ono Pharmaceutical as a new anti-tumor therapeutic agent, and it has become a pioneer for innovative immune checkpoint inhibitors (Ono Pharmaceutical: https://www. opdivo.jp/contents/action/). This immune checkpoint-targeted immunotherapy was selected as "Breakthrough of the Year 2013" by the journal Science as a global revolutionary technology. Currently, Merck, Roche and other major pharmaceutical companies around the world are accelerating their efforts to develop similar antibody-based drugs; this class of therapeutics is gaining so much momentum and attention that the conventional concept of anti-tumor therapy is being overturned.

\section{ACTIVITIES FOR BOVINE LEUKEMIA CONTROL IN JAPAN}

Bovine leukemia is primarily characterized by increased leukocytes and systemic malignant lymphosarcoma. The causative factors of bovine leukemia can be divided into viral and non-viral. Non-viral bovine leukemia is sporadic and can be subdivided into calf type, thymic type and cutaneous type involving unknown causes. On the other hand, enzootic bovine leukemia, which is caused by BLV, accounts for the vast majority of cases of bovine leukemia, and its prevalence continues to increase. BLV infections are latent in the aleukemic (AL) state, but can emerge as persistent lymphocystosis (PL) with non-malignant polyclonal expansion of $\mathrm{CD}^{+} \mathrm{B}$-cells that predominantly harbor BLV provirus and rarely as malignant B-cell lymphoma in various lymph nodes after long periods of latency [25]. The progression of enzootic bovine leukemia is accompanied by marked suppression of cell-mediated immunity $[8,9,16]$, and as the pathogenetic mechanism remains unknown, there are no effective vaccines or therapeutic methods available, meaning that affected animals eventually die. Bovine leukemia was designated as a communicable disease obligated to notify under the Act on Domestic Animal Infectious Diseases Control when it was revised in 1997. In 2015, 
Table 2. Change of immune inhibitory molecules in the cause of bovine leukemia virus infection

\begin{tabular}{lcccccc}
\hline \multirow{2}{*}{ Receptor/Ligand } & \multirow{2}{*}{ Uninfected } & Infected & \multicolumn{3}{c}{ (disease status) } & \multirow{2}{*}{ References } \\
\cline { 3 - 5 } & & & $\mathrm{AL}$ & $\mathrm{PL}$ & Lymphoma & \\
\hline PD-1/PD-L1 & $\rightarrow / \rightarrow$ & $\uparrow / \uparrow$ & $\rightarrow / \rightarrow$ & $\uparrow / \uparrow$ & $\uparrow / \uparrow$ & {$[11-14]$} \\
LAG-3/MHCclass II & $\rightarrow / \rightarrow$ & $\uparrow / \uparrow$ & $\rightarrow / \rightarrow$ & $\uparrow / \uparrow$ & N.D & {$[17,41]$} \\
Tim-3/Gal-9 & $\rightarrow / \rightarrow$ & $\uparrow / \uparrow$ & $\uparrow / \uparrow$ & $\uparrow / \uparrow$ & $\uparrow / \uparrow$ & {$[30]$} \\
CTLA-4/CD80, CD86 & $\rightarrow / \mathrm{N} . \mathrm{D}$ & $\uparrow / \mathrm{N} . \mathrm{D}$ & $\rightarrow / \mathrm{N} . \mathrm{D}$ & $\uparrow / \mathrm{N} . \mathrm{D}$ & $\mathrm{N} . \mathrm{D}$ & {$[47]$} \\
\hline
\end{tabular}

N.D: not demonstrated.

2,896 cases of bovine leukemia were reported (of which the largest number of 494 cases occurred in Hokkaido), representing the disease reported in a greater number than any other bovine disease required to monitor by the Act (http://www.maff.go.jp/j/ syouan/douei/kansi_densen/kansi_densen.html). This number is 29.3-fold the number of cases reported in 1998 (96 affected animals), indicating that the increase has not yet been halted. Requests for urgent measures against this disease have been voiced very frequently by people practicing veterinary medicine and animal husbandry. However, a large-scale survey conducted by the National Institute of Animal Health using specimens collected from 2009 to 2011 showed an approximate BLV-positive rate of $35 \%$, demonstrating the difficulty of implementing any project to select and replace infected cattle [26].

\section{DEVELOPMENT OF NOVEL STRATEGY FOR PREVENTION AND TREATMENT OF BOVINE LEUKEMIA VIRUS INFECTION}

Comparative analyses of BLV-infected cattle by clinical condition have suggested that animals with a high viral load and persistent lymphocytosis are at a high risk of disease onset, often serving as infection sources [34], have a high risk of vertical transmission [24] and have increased levels of $\mathrm{CD} 4^{+} \mathrm{CD} 25^{+} \mathrm{Foxp} 3^{+}$Treg cells, showing increased susceptibility to opportunistic infections due to transforming growth factor-beta produced by Treg cells, which reduces the production of interferon-gamma and tumor necrosis factor-alpha by $\mathrm{CD}^{+} \mathrm{T}$ cells and impairs cellular immunity mediated mainly by the cytotoxic activity of NK cells $[28,48]$. Moreover, the proliferative ability of lymphocytes in response to BLV was also significantly reduced in cattle with persistent lymphocytosis, and lymphocytes were found to produce reduced levels of anti-viral cytokines, such as IFN- $\gamma$, IL-2 and IL-12 [13, 18]. Therefore, we analyzed the expression of PD-1 and its ligand, PD-L1. Results showed that the PD-1 expression in $\mathrm{CD}^{+}$and $\mathrm{CD}^{+}$cells and the PD-L1 expression in virus-infected B cells increase as the disease progresses. Furthermore, PD-L1 expression negatively correlated with the IFN- $\gamma$ expression level, an indicator of immunosuppression, while positively correlating with leukocyte count, virus titer and provirus level. Antibodies to bovine PD-1 and PD-L1 were established, and the results from PD-1 and PD-L1 binding inhibition assays confirmed that they activated anti-viral immunity and that the increase in IFN- $\gamma$ production positively correlated with the PD-1 expression rate on $\mathrm{CD}^{+}{ }^{+} \mathrm{T}$ cells. And also, recombinant bovine PD-L2 (PD-L2-Ig) significantly enhanced IFN- $\gamma$ production from virus antigens-stimulated PBMCs derived from BLV-infected cattle. Interestingly, the PD-L2-Ig-induced IFN- $\gamma$ production was further enhanced by treatment with anti-bovine PD-1 antibody [27]. These results indicated that the PD-1/PD-L pathway constitutes a part of the immunosuppressive mechanism in bovine leukemia (Table 2) [11-14, 18]. We also analyzed immunosuppressive receptors other than the PD-1/PD-L1 pathway, such as lymphocyte-activation gene 3 (LAG-3) [17, 41], T-cell immunoglobulin and mucin domain-containing protein 3 (Tim-3) [30], and cytotoxic T-lymphocyte antigen 4 (CTLA-4; CD152) [44] expressed in antigen-specific lymphocytes and found that expression levels of LAG-3, Tim-3, CTLA-4 and their ligands on lymphocytes increased as the disease progressed and anti-viral immunity was activated in binding inhibition assays, as was the case for PD-1 (Table 2). Currently, clinical studies of these drugs are being carried out at the Hokkaido University and other institutions.

\section{APPLICATION RESEARCH FOR CONTROL STRATEGY AGAINST CHRONIC DISEASES IN VETERINARY MEDICINE}

Although there are many diseases in cattle involving immune abnormalities (impairments), the mechanisms underlying these diseases remain unknown. Our previous analyses have shown that immunosuppressive factors, such as PD-L1, are also involved in immune suppression seen in diseases other than bovine leukemia, namely Johne's disease [31] and bovine anaplasmosis [29]. Furthermore, recent evidence suggests that immunosuppressive factors, such as PD-1, are involved in the reduced immune function in chronic infectious diseases, such as mastitis, bovine mycoplasmosis and bovine tuberculosis (manuscript in preparation). Our laboratory has been working on the development of a BLV vaccine for many years. It is based on a vaccine antigen that was found to be promising in in vitro studies. However, although we tried various procedures, the vaccine did not prevent infection or even disease onset despite the fact that effector cells were present in vivo (data not shown). Results from the present analysis suggested that the virus's immune evasion mechanism for lymphocyte exhaustion might be related to the ineffectiveness of the vaccine. Future measures against chronic infectious diseases will require the development of a new, pre-emptive control method that targets this formidable immune evasion mechanism. To achieve this goal, results from more detailed analyses of immune exhaustion in other chronic infections are awaited. For use in humans, several immune checkpoint-targeting biopharmaceuticals have been 
successively developed, including those described above, and they are being actively tested in clinical trials. In the future, it is anticipated that they will be applied to veterinary medicine and animal husbandry, including diseases in cattle.

ACKNOWLEDGMENTS. This study was supported by grants-in-Aid for Scientific Research from the Japan Society for the Promotion of Science (JSPS), and by special grants for the Promotion of Basic Research Activities for Innovative Biosciences from the National Agriculture and Food Research Organization, Bio-oriented Technology Research Advancement Institution (BRAIN) and Science and Technology Research Promotion Program for Agriculture, Forestry, Fisheries.

\section{REFERENCES}

1. Achleitner, A., Clark, M. E. and Bienzle, D. 2011. T-regulatory cells infected with feline immunodeficiency virus up-regulate programmed death-1 (PD-1). Vet. Immunol. Immunopathol. 143: 307-313. [Medline] [CrossRef]

2. Barber, D. L., Wherry, E. J., Masopust, D., Zhu, B., Allison, J. P., Sharpe, A. H., Freeman, G. J. and Ahmed, R. 2006. Restoring function in exhausted CD8 T cells during chronic viral infection. Nature 439: 682-687. [Medline] [CrossRef]

3. Chiku, V. M., Silva, K. L., de Almeida, B. F., Venturin, G. L., Leal, A. A., de Martini, C. C., de Rezende Eugênio, F., Dos Santos, P. S. and de Lima, V. M. 2016. PD-1 function in apoptosis of T lymphocytes in canine visceral leishmaniasis. Immunobiology 221: 879-888. [Medline] [CrossRef]

4. Day, C. L., Kaufmann, D. E., Kiepiela, P., Brown, J. A., Moodley, E. S., Reddy, S., Mackey, E. W., Miller, J. D., Leslie, A. J., DePierres, C., Mncube, Z., Duraiswamy, J., Zhu, B., Eichbaum, Q., Altfeld, M., Wherry, E. J., Coovadia, H. M., Goulder, P. J., Klenerman, P., Ahmed, R., Freeman, G. J. and Walker, B. D. 2006. PD-1 expression on HIV-specific T cells is associated with T-cell exhaustion and disease progression. Nature 443: 350-354. [Medline] [CrossRef]

5. Dong, H., Strome, S. E., Salomao, D. R., Tamura, H., Hirano, F., Flies, D. B., Roche, P. C., Lu, J., Zhu, G., Tamada, K., Lennon, V. A., Celis, E. and Chen, L. 2002. Tumor-associated B7-H1 promotes T-cell apoptosis: a potential mechanism of immune evasion. Nat. Med. 8: 793-800. [Medline] [CrossRef]

6. Esch, K. J., Juelsgaard, R., Martinez, P. A., Jones, D. E. and Petersen, C. A. 2013. Programmed death 1-mediated T cell exhaustion during visceral leishmaniasis impairs phagocyte function. J. Immunol. 191: 5542-5550. [Medline] [CrossRef]

7. Folkl, A., Wen, X., Kuczynski, E., Clark, M. E. and Bienzle, D. 2010. Feline programmed death and its ligand: characterization and changes with feline immunodeficiency virus infection. Vet. Immunol. Immunopathol. 134: 107-114. [Medline] [CrossRef]

8. Frie, M. C. and Coussens, P. M. 2015. Bovine leukemia virus: a major silent threat to proper immune responses in cattle. Vet. Immunol. Immunopathol. 163: 103-114. [Medline] [CrossRef]

9. Gillet, N., Florins, A., Boxus, M., Burteau, C., Nigro, A., Vandermeers, F., Balon, H., Bouzar, A. B., Defoiche, J., Burny, A., Reichert, M., Kettmann, R. and Willems, L. 2007. Mechanisms of leukemogenesis induced by bovine leukemia virus: prospects for novel anti-retroviral therapies in human. Retrovirology 4: 18. [Medline] [CrossRef]

10. Hartley, G., Faulhaber, E., Caldwell, A., Coy, J., Kurihara, J., Guth, A., Regan, D. and Dow, S. 2016. Immune regulation of canine tumour and macrophage PD-L1 expression. Vet. Comp. Oncol.; [Epub ahead of print]. [Medline] [CrossRef]

11. Ikebuchi, R., Konnai, S., Okagawa, T., Nishimori, A., Nakahara, A., Murata, S. and Ohashi, K. 2014. Differences in cellular function and viral protein expression between IgM ${ }^{\text {high }}$ and IgM ${ }^{\text {low }}$ B-cells in bovine leukemia virus-infected cattle. J. Gen. Virol. 95: 1832-1842. [Medline] [CrossRef]

12. Ikebuchi, R., Konnai, S., Okagawa, T., Yokoyama, K., Nakajima, C., Suzuki, Y., Murata, S. and Ohashi, K. 2014. Influence of PD-L1 cross-linking on cell death in PD-L1-expressing cell lines and bovine lymphocytes. Immunology 142: 551-561. [Medline] [CrossRef]

13. Ikebuchi, R., Konnai, S., Shirai, T., Sunden, Y., Murata, S., Onuma, M. and Ohashi, K. 2011. Increase of cells expressing PD-L1 in bovine leukemia virus infection and enhancement of anti-viral immune responses in vitro via PD-L1 blockade. Vet. Res. (Faisalabad) 42: 103. [Medline] [CrossRef]

14. Ikebuchi, R., Konnai, S., Sunden, Y., Onuma, M. and Ohashi, K. 2010. Molecular cloning and expression analysis of bovine programmed death-1. Microbiol. Immunol. 54: 291-298. [Medline]

15. Ishida, Y., Agata, Y., Shibahara, K. and Honjo, T. 1992. Induced expression of PD-1, a novel member of the immunoglobulin gene superfamily, upon programmed cell death. EMBO J. 11: 3887-3895. [Medline]

16. Kabeya, H., Ohashi, K. and Onuma, M. 2001. Host immune responses in the course of bovine leukemia virus infection. J. Vet. Med. Sci. 63: 703-708. [Medline] [CrossRef]

17. Konnai, S., Suzuki, S., Shirai, T., Ikebuchi, R., Okagawa, T., Sunden, Y., Mingala, C. N., Onuma, M., Murata, S. and Ohashi, K. 2013. Enhanced expression of LAG-3 on lymphocyte subpopulations from persistently lymphocytotic cattle infected with bovine leukemia virus. Comp. Immunol. Microbiol. Infect. Dis. 36: 63-69. [Medline] [CrossRef]

18. Konnai, S., Usui, T., Ohashi, K. and Onuma, M. 2003. The rapid quantitative analysis of bovine cytokine genes by real-time RT-PCR. Vet. Microbiol. 94: 283-294. [Medline] [CrossRef]

19. Leite, F. L., Eslabão, L. B., Pesch, B., Bannantine, J. P., Reinhardt, T. A. and Stabel, J. R. 2015. ZAP-70, CTLA-4 and proximal T cell receptor signaling in cows infected with Mycobacterium avium subsp. paratuberculosis. Vet. Immunol. Immunopathol. 167: 15-21. [Medline] [CrossRef]

20. Maekawa, N., Konnai, S., Ikebuchi, R., Okagawa, T., Adachi, M., Takagi, S., Kagawa, Y., Nakajima, C., Suzuki, Y., Murata, S. and Ohashi, K. 2014. Expression of PD-L1 on canine tumor cells and enhancement of IFN- $\gamma$ production from tumor-infiltrating cells by PD-L1 blockade. PLOS ONE 9: e98415. [Medline] [CrossRef]

21. Maekawa, N., Konnai, S., Okagawa, T., Nishimori, A., Ikebuchi, R., Izumi, Y., Takagi, S., Kagawa, Y., Nakajima, C., Suzuki, Y., Kato, Y., Murata, S. and Ohashi, K. 2016. Immunohistochemical Analysis of PD-L1 Expression in Canine Malignant Cancers and PD-1 Expression on Lymphocytes in Canine Oral Melanoma. PLOS ONE 11: e0157176. [Medline] [CrossRef]

22. Matsuyama-Kato, A., Murata, S., Isezaki, M., Kano, R., Takasaki, S., Ichii, O., Konnai, S. and Ohashi, K. 2012. Molecular characterization of immunoinhibitory factors PD-1/PD-L1 in chickens infected with Marek's disease virus. Virol. J. 9: 94. [Medline] [CrossRef]

23. Matsuyama-Kato, A., Murata, S., Isezaki, M., Takasaki, S., Kano, R., Konnai, S. and Ohashi, K. 2014. Expression analysis of programmed death ligand 2 in tumors caused by the avian oncovirus Marek's disease virus. Arch. Virol. 159: 2123-2126. [Medline] [CrossRef]

24. Mekata, H., Sekiguchi, S., Konnai, S., Kirino, Y., Honkawa, K., Nonaka, N., Horii, Y. and Norimine, J. 2015. Evaluation of the natural perinatal transmission of bovine leukaemia virus. Vet. Rec. 176: 254. [Medline] [CrossRef]

25. Mirsky, M. L., Olmstead, C. A., Da, Y. and Lewin, H. A. 1996. The prevalence of proviral bovine leukemia virus in peripheral blood mononuclear cells at two subclinical stages of infection. J. Virol. 70: 2178-2183. [Medline] 
26. Murakami, K., Kobayashi, S., Konishi, M., Kameyama, K. and Tsutsui, T. 2013. Nationwide survey of bovine leukemia virus infection among dairy and beef breeding cattle in Japan from 2009-2011. J. Vet. Med. Sci. 75: 1123-1126. [Medline] [CrossRef]

27. Nishimori, A., Konnai, S., Ikebuchi, R., Okagawa, T., Nakajima, C., Suzuki, Y., Mingala, C. N., Murata, S. and Ohashi, K. 2014. Identification and characterization of bovine programmed death-ligand 2. Microbiol. Immunol. 58: 388-397. [Medline] [CrossRef]

28. Ohira, K., Nakahara, A., Konnai, S., Okagawa, T., Nishimori, A., Maekawa, N., Ikebuchi, R., Kohara, J., Murata, S. and Ohashi, K. 2016. Bovine leukemia virus reduces anti-viral cytokine activities and NK cytotoxicity by inducing TGF- $\beta$ secretion from regulatory T cells. Immun. Inflamm. Dis. 4: 52-63. [Medline] [CrossRef]

29. Okagawa, T., Konnai, S., Deringer, J. R., Ueti, M. W., Scoles, G. A., Murata, S., Ohashi, K. and Brown, W. C. 2016. Cooperation of PD-1 and LAG3 contributes to T-cell exhaustion in Anaplasma marginale-infected cattle. Infect. Immun. 84: 2779-2790. [Medline] [CrossRef]

30. Okagawa, T., Konnai, S., Ikebuchi, R., Suzuki, S., Shirai, T., Sunden, Y., Onuma, M., Murata, S. and Ohashi, K. 2012. Increased bovine Tim-3 and its ligand expressions during bovine leukemia virus infection. Vet. Res. (Faisalabad) 43: 45. [Medline] [CrossRef]

31. Okagawa, T., Konnai, S., Nishimori, A., Ikebuchi, R., Mizorogi, S., Nagata, R., Kawaji, S., Tanaka, S., Kagawa, Y., Murata, S., Mori, Y. and Ohashi, K. 2015. Bovine Immunoinhibitory Receptors Contribute to Suppression of Mycobacterium avium subsp. paratuberculosis-Specific T-Cell Responses. Infect. Immun. 84: 77-89. [Medline] [CrossRef]

32. Okazaki, T. and Honjo, T. 2007. PD-1 and PD-1 ligands: from discovery to clinical application. Int. Immunol. 19: 813-824. [Medline] [CrossRef]

33. Okazaki, T., Maeda, A., Nishimura, H., Kurosaki, T. and Honjo, T. 2001. PD-1 immunoreceptor inhibits B cell receptor-mediated signaling by recruiting src homology 2-domain-containing tyrosine phosphatase 2 to phosphotyrosine. Proc. Natl. Acad. Sci. U.S.A. 98: 13866-13871. [Medline] [CrossRef]

34. Ooshiro, M., Konnai, S., Katagiri, Y., Afuso, M., Arakaki, N., Tsuha, O., Murata, S. and Ohashi, K. 2013. Horizontal transmission of bovine leukemia virus from lymphocytotic cattle, and beneficial effects of insect vector control. Vet. Rec. 173: 527. [Medline] [CrossRef]

35. Palomares, R. A., Hurley, D. J., Woolums, A. R., Parrish, J. E. and Brock, K. V. 2014. Analysis of mRNA expression for genes associated with regulatory T lymphocytes (CD25, FoxP3, CTLA4, and IDO) after experimental infection with bovine viral diarrhea virus of low or high virulence in beef calves. Comp. Immunol. Microbiol. Infect. Dis. 37: 331-338. [Medline] [CrossRef]

36. Parvizi, P., Andrzejewski, K., Read, L. R., Behboudi, S. and Sharif, S. 2010. Expression profiling of genes associated with regulatory functions of T-cell subsets in Marek's disease virus-infected chickens. Avian Pathol. 39: 367-373. [Medline] [CrossRef]

37. Regan, D., Guth, A., Coy, J. and Dow, S. 2016. Cancer immunotherapy in veterinary medicine: Current options and new developments. Vet. J. 207: 20-28. [Medline] [CrossRef]

38. Richmond, O., Cecere, T. E., Erdogan, E., Meng, X. J., Piñeyro, P., Subramaniam, S., Todd, S. M. and LeRoith, T. 2015. The PD-L1/CD86 ratio is increased in dendritic cells co-infected with porcine circovirus type 2 and porcine reproductive and respiratory syndrome virus, and the PD-L1/PD-1 axis is associated with anergy, apoptosis, and the induction of regulatory T-cells in porcine lymphocytes. Vet. Microbiol. 180: 223-229. [Medline] [CrossRef]

39. Richmond, O., Cecere, T. E., Erdogan, E., Meng, X. J., Piñeyro, P., Subramaniam, S., Todd, S. M. and LeRoith, T. 2015. PD-L1 expression is increased in monocyte derived dendritic cells in response to porcine circovirus type 2 and porcine reproductive and respiratory syndrome virus infections. Vet. Immunol. Immunopathol. 168: 24-29. [Medline] [CrossRef]

40. Schaut, R. G., Lamb, I. M., Toepp, A. J., Scott, B., Mendes-Aguiar, C. O., Coutinho, J. F., Jeronimo, S. M., Wilson, M. E., Harty, J. T., Waldschmidt, T. J. and Petersen, C. A. 2016. Regulatory IgDhi B Cells Suppress T Cell Function via IL-10 and PD-L1 during Progressive Visceral Leishmaniasis. J. Immunol. 196: 4100-4109. [Medline] [CrossRef]

41. Shirai, T., Konnai, S., Ikebuchi, R., Okagawa, T., Suzuki, S., Sunden, Y., Onuma, M., Murata, S. and Ohashi, K. 2011. Molecular cloning of bovine lymphocyte activation gene-3 and its expression characteristics in bovine leukemia virus-infected cattle. Vet. Immunol. Immunopathol. 144: 462-467. [Medline] [CrossRef]

42. Shosu, K., Sakurai, M., Inoue, K., Nakagawa, T., Sakai, H., Morimoto, M., Okuda, M., Noguchi, S. and Mizuno, T. 2016. Programmed Cell Death Ligand 1 Expression in Canine Cancer. In Vivo 30: 195-204. [Medline]

43. Singh, P. and Ramamoorthy, S. 2016. Immune gene expression in swine macrophages expressing the Torque Teno Sus Virus1 (TTSuV1) ORF-1 and 2 proteins. Virus Res. 220: 33-38. [Medline] [CrossRef]

44. Sow, F. B., Gallup, J. M., Derscheid, R., Krishnan, S. and Ackermann, M. R. 2012. Ontogeny of the immune response in the ovine lung. Immunol. Invest. 41: 304-316. [Medline] [CrossRef]

45. Sow, F. B., Gallup, J. M., Krishnan, S., Patera, A. C., Suzich, J. and Ackermann, M. R. 2011. Respiratory syncytial virus infection is associated with an altered innate immunity and a heightened pro-inflammatory response in the lungs of preterm lambs. Respir. Res. 12: 106. [Medline] [CrossRef]

46. Sow, F. B., Gallup, J. M., Olivier, A., Krishnan, S., Patera, A. C., Suzich, J. and Ackermann, M. R. 2011. Respiratory syncytial virus is associated with an inflammatory response in lungs and architectural remodeling of lung-draining lymph nodes of newborn lambs. Am. J. Physiol. Lung Cell. Mol. Physiol. 300: L12-L24. [Medline] [CrossRef]

47. Suzuki, S., Konnai, S., Okagawa, T., Ikebuchi, R., Nishimori, A., Kohara, J., Mingala, C. N., Murata, S. and Ohashi, K. 2015. Increased expression of the regulatory T cell-associated marker CTLA-4 in bovine leukemia virus infection. Vet. Immunol. Immunopathol. 163: 115-124. [Medline] [CrossRef]

48. Suzuki, S., Konnai, S., Okagawa, T., Ikebuchi, R., Shirai, T., Sunden, Y., Mingala, C. N., Murata, S. and Ohashi, K. 2013. Expression analysis of Foxp3 in T cells from bovine leukemia virus infected cattle. Microbiol. Immunol. 57: 600-604. [Medline] [CrossRef]

49. Sznol, M. and Chen, L. 2013. Antagonist antibodies to PD-1 and B7-H1 (PD-L1) in the treatment of advanced human cancer. Clin. Cancer Res. 19: 1021-1034. [Medline] [CrossRef]

50. Tagawa, M., Maekawa, N., Konnai, S. and Takagi, S. 2016. Evaluation of Costimulatory Molecules in Peripheral Blood Lymphocytes of Canine Patients with Histiocytic Sarcoma. PLOS ONE 11: e0150030. [Medline] [CrossRef]

51. Thompson, R. H., Kuntz, S. M., Leibovich, B. C., Dong, H., Lohse, C. M., Webster, W. S., Sengupta, S., Frank, I., Parker, A. S., Zincke, H., Blute, M. L., Sebo, T. J., Cheville, J. C. and Kwon, E. D. 2006. Tumor B7-H1 is associated with poor prognosis in renal cell carcinoma patients with long-term follow-up. Cancer Res. 66: 3381-3385. [Medline] [CrossRef]

52. Velu, V., Titanji, K., Zhu, B., Husain, S., Pladevega, A., Lai, L., Vanderford, T. H., Chennareddi, L., Silvestri, G., Freeman, G. J., Ahmed, R. and Amara, R. R. 2009. Enhancing SIV-specific immunity in vivo by PD-1 blockade. Nature 458: 206-210. [Medline] [CrossRef]

53. Wu, C., Zhu, Y., Jiang, J., Zhao, J., Zhang, X. G. and Xu, N. 2006. Immunohistochemical localization of programmed death-1 ligand-1 (PD-L1) in gastric carcinoma and its clinical significance. Acta Histochem. 108: 19-24. [Medline] [CrossRef]

54. Yue, F., Cheng, A., Zhu, Y., Li, P., Zhang, Y., Sun, G., Wang, M. and Wang, X. 2015. Overexpression of programmed death ligands in naturally occurring postweaning multisystemic wasting syndrome. Viral Immunol. 28: 101-106. [Medline] [CrossRef]

55. Yue, F., Zhu, Y. P., Zhang, Y. F., Sun, G. P., Yang, Y., Guo, D. G., Wang, A. G., Li, B. W., Yin, M., Cheng, A. C., Wang, M. S. and Wang, X. N. 2014. Up-regulated expression of PD-1 and its ligands during acute Classical Swine Fever virus infection in swine. Res. Vet. Sci. 97: 251-256. [Medline] [CrossRef] 